for righteousness and human brotherhood ; they and their fellows, on either side of the Atlantic, are to us a grander legacy than Marathon to Athens. And when our systems of instruction shall be rounded out to their completion, the great books that our English-speaking men have made shall do their proper part in making men.

\title{
Colgate University.
}

John Greene.

\section{ON SUPERVISING PRIVATE SCHOOLS.}

In his argument that appears in the September issue of the ScHOOL REvIEW, urging government supervision of private schools, Dr. Mackenzie is clearly right in the statement that school supervision is a leading question in education at the present day. But surely he must expect that many interested in education will take issue with him when he lays down the proposition that private schools should be so supervised.

While men may agree that our entire educational system has faults that should be relieved, there must in the nature of things be a wide variance of opinion as to the corrective principle to be applied.

There can be no doubt that lack of unity of purpose, definiteness of aim, and coherence of organization is the distinctive defect of educational institutions in the United States to-day. The absence of proper relations between secondary schools and colleges, and of uniform requirements for admission to college, the inequality of the work leading to the bachelor's degree, and the almost total lack of adequate requirement for admission to most professional schools are the results of antecedent conditions that have tended to bring educational matters in our country to their present unfortunate status.

Educational traditions and methods among us are the outgrowth of our own peculiar environment and conditions of life. Freedom, liberty, and absence of restraint of older conventionalisms mark the distinctly American movements in politics and sociology. Education, too, among us has been evolved from conditions and facts that were present, at home with us ; not foreign, 
not imposed upon us from above, but grown of native root in native soil. It is quite possible that its growth has been all too untended and unnurtured, and that like "Topsy" it has simply "growed." Be that as it may, there can be little doubt that our educational institutions are indigenous, a home product, and hence have a fitness of a high order to accomplish their work. To this spontaneity is attributable their individuality and independence. Valuable as is this native quality of education in the United States, there are evils attending it that are suggested in the separateness that exists between our various institutions of the same and of different grades. From this isolation, as a source, comes lack of coherence and unity. There can be but one result to all this ; there must be a great waste of power. Misdirected energy may be more disastrous in its effects than unused energy. Our educational institutions are suffering from the results of unwisely applied pedagogic power.

Uniform and symmetrical organization can alone prevent this waste of force and give a wise and economic application to the great work awaiting education in this country to-day. Strong, wise, catholic supervision is needed. Whence should spring the authority to supervise? what institutions should be supervised? and how? The answering of these questions will disclose differences of opinion more or less radical.

It occurs to us immediately that all public schools are supervised in the United States. The thought that they are in the majority of cases wisely and patriotically supervised would not occur to the mind with the same immediateness. While waiving the question to what point the state should be responsible for the education of its children, and whether a uniformly wise supervivision has been arrived at for the public schools, as Americans we all gladly admit the inestimable value to the nation of our public schools, and admit the necessity of State and municipal supervision of all schools whose origin is due to State or national enactment.

There is, however, a serious importance to the argument against paternalism in government, and there are apparent limits within which government aid and government control may be solicited among a free people. The function of government is not to absorb those duties that belong to "intelligent individualism," as Dr. Mackenzie phrases it. "Intelligent individualism is now the 
regulative principle." There is such an influence as the genius of a people ; and the genius of the American people is distinctly opposed to indiscriminate interference of centralized government in some at least of what may be even the dearest interests of the people. "Government" is not always a safe word with which to conjure. There are great needs of the people that will not answer its summons. Surely no true American doubts the wisdom of the divorce of church and state in the United States. Yet the religious interests of the people are transcendent interests. The duty of government supervision of the interests of the citizens is not in the ratio of the preciousness of the special interests involved; were this so then the argument that Dr. Mackenzie constructs on the needed supervision of the pilotage system of New York might hold, as he seems to think it should, as an argument for government supervision of private schools. We might indeed then go to the fish market and shambles, as we are invited to, that we might discover some adequate arrangement of supervision for our private schools.

The thought certainly must occur to Dr. Mackenzie that, in dealing with questions of public health and personal safety of life and limb and the training of soldiers and sailors for public defence, he is dealing with the most undisputed functions of government, but that, when he approaches the question of the relation of government to schools that are the result of the efforts of a single individual, or of a corporation, to achieve certain definite ends in education, he is concerned with an entirely different kind of facts, facts so unrelated that they are not akin to those he has marshalled in his argument, and so cause his illustrative argument to fail through lack of parallelism.

Does not his argument really fall into the following syllogistic form? The function of government is to secure the good of its citizens. Governmental supervision of a fishmonger secures the good of its citizens. Therefore government should supervise private schools. Dr. Mackenzie will not care long to meet his own argument when reduced to a form that proves its own absurdity. On the sound principle of keeping the government within those lines that clearly mark its competency private schools should not be supervised by the government.

"The sure taint of politics," using Dr. Mackenzie's words, is to be deprecated. The condition of the public schools in many 
of our great cities is too well known to allow us to wink out of sight the inevitable damage that would come to private schools if placed under government supervision. One immense advantage private schools have to-day over the public school is freedom from the ignorance and enmity of the public school board. The autonomy that is theirs has enabled them in many instances to exercise a wise and brave leadership in educational matters. They have cherished an alert and inquisitive spirit of scholarship that has resulted in a hospitality to truth that has made them the proper field for experiment and progress. The rose is no remoter from the thorn than is the thorn from the rose. If the lack of uniformity that we regret in private schools has its faults, it has also its excellencies. The unique school is possible under it, and the unique teacher. A Sam Taylor may be evolved who can use both hands and all his brains in fashioning a Phillips Andover. Give us ten thousand times over an unsupervised Rugby with a Thomas Arnold at its head training, inspiring, making men, rather than a score of German gymnasien supervised and desiccated and refined to the highest degree of German formalism and routine.

While believing that private schools should not be supervised by boards appointed by the government, and certainly not for the reasons advanced by Dr. Mackenzie, I am entirely ready to admit, as already stated, that supervision is desirable and necessary. Our contention then with Dr. Mackenzie is not as to the question of supervision, but as to the origin of the supervising power.

For the purpose of economy of force, without which no educational system can be wise, supervisory power should be exercised over all preparatory schools, whether public or private, by a commission appointed by the faculties of the colleges and universities. Oneness of aim, symmetry of development and coherence would then be secured, and the enormous friction of the present state of affairs greatly reduced. The colleges and universities are the rightful source of such influence as should be found in a supervising board for secondary schools.

Intelligent supervision would thus be possible, the corruption of politics impossible, academic and not personal partisan influence would be operative, and the leaven coming from the natural source, the higher institutions, would tend to raise the entire grade of preparatory schools to the high level of unquestioned usefulness and harmony of effort and aim. 
However, before such a supervising body could be thus appointed with regulative power over private and public schools, the colleges themselves should be required to give clear definitions of much of the nomenclature current among them, and should be expected to come to full agreement on several points of variance. What will they understand the degree of bachelor of arts to mean, or the master's degree? What work in quality and amount shall lead to these degrees?

Shall there not be a practical ayreement in the character of the requirements for admission to college for candidates for the same degree?

Shall there not be an agreement as to the character and amount of training that lead to the bachelor's degree?

Shall not the old inflexibility be sufficiently relaxed to allow the acceptance of a real equivalency of work ?

An agreement on these and on points that may further be suggested should be reached before the colleges can be themselves in the degree of harmony to enable them to arrange a consistent program for the scondary schools.

We all hope to hear that a large concurrence has been reached by the members of the various conferences appointed by the $\mathrm{Na}$ tional Association, whose report is to be made by their Chairman, President Eliot, at the forthcoming meeting of colleges and preparatory schools in New Haven.

All signs point to an educational awakening such as this country has never known. But in our spasm for a regulative principle let us be careful whence we invoke our king. Let us never forget that even so good an end as method is not to be the ultimate result of the teacher's work. We are not to stop short even with the high art of training our pupils to think. Feeling, emotion, idealism must be the great objective. Formalism and mere uninspired method can never secure these great ends. Let us not feel in our perplexity that we can bring in the strong arm of state authority as a deus ex machina to deliver us.

D. W. Abercrombie.

Worcester Academy', Oct. 9, I\&93. 


\section{To the Editors of the School Review:}

GENTLEMEN :-Let me thank you for sending me advance sheets of the article by Dr. Mackenzie on "the supervision of private schools by the state." It gives me pleasure to comply with your request that I should state my view of the question.

I have read the article with much interest and sincerely sympathize with the author's earnestness in the discussion of an important topic. Doubtless the large number of private and endowed schools in this country would be greatly improved by a systematic method of organization and supervision. The serious words of Horace Mann, fifty years ago, quoted by the author, are applicable to many of these schools to-day. But I doubt whether as many of these schools, not subject to supervision and with no bond of union, can now be found in the State of New York, as in New England and in other States, with which the author may be more familiar. All readers of Dr. Mackenzie's article should know, and doubtless most of them do know that the State of New York has a systematic method of organization and supervision, which may be accepted by all her secondary schools and which is accepted by most of them. This plan corresponds in general and in many particulars with that which the Doctor advocates so wisely and well. To this organization has been given very properly the name "University." To this university all incorporated institutions of academic and higher education in the State, may be admitted by the Regents. The object of the university is in all proper ways to encourage, promote and supervise academic and higher education. Since 1784 , for Io9 years, higher education in the State of New York has been efficiently and increasingly "supervised," until now the university comprises more than 500 educational institutions, teaching nearly 64,000 pupils and expending during the last year more than seven million dollars. This work of supervision is carried on through published reports and by frequent visitation and careful inspection and frequent examinations. Besides, by calling together the teachers of the State annually in a convocation at the capital in Albany, the Regents encourage the comparison and discussion of educational opinions and practice. For thirty-one years, these convocations have been held with increasing interest and a larger attendance, until an accomplished editor of a leading educational journal has recently said: "I really think the Convocation is to-day the most 
important meeting of teachers in this country; and I am sure it is going to be recognized more and more by prominent teachers in other States as an occasion they cannot afford to miss."

The more carefully the supervisory work of "the University of the State of New York" is examined, the more plainly will it appear that what Horace Mann called for fifty years ago, is found in it. We have in the university a "living institution, an animate organization, which can and does at least embody and diffuse all that is now known in education, and thereby saves every year hundreds of children from being sacrificed to experiments which have been a hundred times exploded." Through the agency of the university every teacher can "lay tribute upon capitalized experience."

We have then in the university of the State of New York, as managed by the Regents an example of that systematic supervision which Dr. Mackenzie advocates. Most endowed schools in the State of New York are already members of the university. No such school in this State need be longer isolated. All may enjoy the stimulating as well as regulating influence of such association. No essential rights need be surrendered. The Regents practice no "meddlesome paternalism." Every such chartered school gains a valuable recognition and association. Corporate rights are made more permanent and more practically efficient. Considerable money is apportioned annually to each school.

Why should not similar organizations be established in other States?

Glens Falls, N. Y. Anson J. Upson, Chancellor of the University of the State of New York.

\section{FAILURE TO APPRECIATE CONDITIONS.}

It is late in the day to argue the general advantages of supervision as Professor Mackenzie does in the September number of the School. REviEw. It would be more to the point to analyze the conditions of public and private fitting schools. Supervision has done little for public secondary schools. Successful fitting 
schools, private as well as public, keep their eyes steadily upon the grade of college for whicin they fit. The colleges of any grade can change the emphasis of their fitting schools from Greek to the sciences, or from text-book study to laboratory practice at will. No supervision can do what they do so easily regarding the variety, quality or quantity of work. Sharpshooters can never be supervised. Their success is in the reliability of their aim. Fitting schools are sharpshooters. Some aim at Harvard and Yale, others at Amherst and Williams, others at Tufts and Collsy and they hit their mark. Their need is an eye trained to hold the mark steadily, undiverted by undue supervisory interference.

The public school may be too intent upon preparing the few for college examinations, and the private school may be too thoughtful of the many who will not take the examination, but supervision would hardly change the conditions. The only appreciable aid the secondary schools have had has come from associations and conferences, and these are as open to private as public school teachers. There are not only serious obstacles to the supervision of private fitting schools but there is no appreciable advantage to be gained therefrom.

Boston, Aug. 28, 1893 .

A. E. Winship.

In all great reforms the man who raises issues does a work almost as important as the man who meets them. Dr. Mackenzie's article in the September number of THE ScHOOL REVIEW is not unlikely, therefore, to be epoch-making. Who before hin had ever brought the question of the Supervision of Private Schools into vital relation with the highest interests of " nearly half a million boys and girls, many of whom are to swell the Ioo,ooo enrollment of the five hundred American colleges?" Whatever may be thought of the remedy proposed by Dr. Mackenzie for the improvement of the private schools, which do so large a part of our educational work, there can be no difierence of opinion in regard to the importance of the end or the urgency of the demand it makes upon us.

In re-reading Dr. Mackenzie's article in connection with the comments made upon it by the distinguished educators who dis- 
cuss it in the present issue of the REviEw, I am struck with the large measure of agreement that may be found in all the views presented. With one exception only, all the writers concur in the value of supervision for private secondary schools. Mr. Winship dissents, holding that "supervision has done little for public secondary schools." But the educational history of our own States, even if we ignore the still stronger evidence to be derived from English, French, and German experience, seems to throw considerable doubt upon that proposition. In some cities, and perhaps in some States, the work of supervision may have fallen into incompetent hands ; but this mishap is not so general as to forbid our regarding it as an accident in the operation of a system, which, inherently considered, must be pronounced good. Supervision quickens the teacher's sense of responsibility. Supervision propagates improved, and eradicates defective, principles of education and modes of instruction. Supervision gives to all pupils the benefits which would otherwise be the monopoly of the few. It is as beneficial to the private as to the public school. Mr. Winship thinks that in fitting schools there is no place for supervision : they improve by following in the wake of the college to which they send pupils. Would he, however, not admit that the fitting schools might be greatly benefited by the visitation, say, of a supervisory committee of college professors, who should make suggestions regarding the teaching of their respective specialties? It may be well for the fitting schools to "keep their eyes steadily upon the grade of college for which they fit;" but would not the utterances of the men who compose the college faculty be better than the visual image of the curriculum they lay out? In other words, Mr. Winship seems to me to object, not to every sort of supervision, but only to incompetent and therefore hurtful supervision.

Such supervision as that just suggested is now practised in many States west of New York. The primary object is to have the schools "accredited," so that their graduates may without further examination enter the State university. From Michigan to California this system has commended itself in the light of experience. Why should it not be adopted in the east? It would be a great gain, both for colleges and fitting schools, if by the same act we should gain both a system of supervision and a substitution of the principal's certificate for the college entrance 
examination. The problem is harder to solve in the east because there is not in each State merely one university with which the schools have to deal. But even in the east the case is not hopeless. And Principal Abercrombie, who is not unnaturally jealous of State interference with private schools, points out the path of promise when he says that "supervisory power should be exercised over all preparatory schools, whether public or private, by a commission appointed by the faculties of colleges and universities."

Custom precedes law. The pilotage system of New York, as Dr. Mackenzie has shown, is due to the adoption and legalizing by the legislature of a plan of service initiated and maintained by the voluntary co-operation of merchants and underwriters. If the work of supervision above outlined should ever come into general practice, it would be an easy matter, were it thought advisable thereafter, to have it embodied in mandatory law. Even Dr. Mackenzie could not object to beginning with voluntary supervision. Chancellor Upson has described briefly and clearly how supervision is carried on in New York and shown the capacity of the system for indefinite expansion. But the Regents of New York are a unique body, and though they do well the work for New York, it does not seem probable that "similar organizations" will be established in other States. I mean that there are no germs now in existence out of which such an organization in another State might naturally grow. Voluntary supervision, leading to the substitution of the school certificate for the college entrance examination, seems to me at once the easiest and, with due regard to existing practice, the most natural solution of the problem.

$$
\text { J. G. Schurman. }
$$

